\title{
Energy retrofitting of buildings and hygrothermal performance of building components: Application of the assessment methodology to a case study of social housing
}

\author{
Anna Magrini $^{1 *}$, Stefano Lazzari ${ }^{2}$, Ludovica Marenco ${ }^{3}$ \\ ${ }^{1}$ Dept. Civil Engineering and Architecture, University of Pavia, Via Adolfo Ferrata, Pavia 1 - \\ 27100 , Italy \\ ${ }^{2}$ Dept. Architecture and Design, University of Genova, Stradone S. Agostino, Genova 37 - 16123, \\ Italy \\ ${ }^{3}$ IRE S.p.A. (Infrastrutture Recupero Energia), Via XX Settembre, Genova 41 - 16121, Italy
}

Email: magrini@unipv.it

\begin{abstract}
Any intervention on the envelope/HVAC system of existing buildings should start from the evaluation of the building's envelope energy-saving options.

Typical buildings critical from the energy standpoint are represented by social housings: in this case the energysaving is not possible without the building's envelope renovation. Their energy retrofit towards NZEB should be the next challenge: it is analysed in the present paper by proposing an evaluation procedure that takes into account different constraints and limits imposed by national laws, following the indications of the European Directives.

To illustrate the calculation methodology a case study is examined, by comparing the U-values of the existing walls with the NZEB limits and with the limits considered for the energy refurbishment of the buildings. The insulation improvement of the reference walls depends on both the thermo-physical properties and the thickness of the materials used. The choice of the most suitable combination of material and thickness is related not only to the energy-saving, but also to the risk of vapor condensation that depends on the position of the insulating materials within the wall's structure. Therefore, the outlined procedure takes into account both these aspects. Moreover, as the renovation design process involves a multiplicity of elements and parameters, the proposed procedure could be generalized to consider a wide list of characteristics and constraints that allow to guarantee the most suitable solution with acceptable costs.
\end{abstract}

Keywords: EPBD, Energy Performance, Vapour Condensation Risk, Building Refurbishment, NZEB.

\section{INTRODUCTION}

The EPBD targets (2010) are directed to reach NZEB standard by the year 2019 (new public buildings) and 2021 (all new buildings) [1]. Inside the common general framework for the calculation of the energy performance of buildings (Annex I, [1]), insulation is one of the relevant aspects.

High attention is focused to evaluate the technical and economic feasibility to apply these energy efficiency criteria also to the existing building stock.

The Member States have indicated minimum requirements for the energy performance of building envelope elements (art.4, [1]), according to the Guidelines on the comparative methodology for calculating cost-optimal levels [2], with particular attention to the local climatic conditions (art.1 and Annex III, [1]). To establish the minimum requirements, reference buildings must be defined, considering jointly the following aspects (Annex III):
1. the "reference" characteristics (representative of the intended use and the geographic location, including indoor and outdoor climate conditions, for new and existing buildings);

2. the most suitable energy efficiency packages of measures to be applied;

3. the energy-need reduction obtained by the energy efficiency measures applied;

4. the costs (i.e. the net present value) of the energy efficiency measures, during their expected economic life-cycle;

5. the determination of cost-optimal levels of energy performance requirements.

Therefore, the evaluation methodology and the targets have been defined at European and national level, both for new and existing buildings under renovation.

In detail, while the new buildings must be NZEB since 2019 (public buildings) and 2021 (private buildings), any 
intervention on existing buildings should aim at NZEB goal (retrofit) or, in case this cannot be accomplished, at least at a good level of energy consumption reduction (refurbishment).

As a consequence, taking into account the wide existing building stock, the challenge will be the building retrofit towards NZEB.

In the last years, several studies have been developed on the energy refurbishment towards class A and high performance buildings.

Some solutions towards the class A requirements for existing buildings are used to highlight the most suitable interventions for the energy performance retrofit [3].

Business investors, public bodies and local communities, aimed at reducing to zero carbon emission in localized urban environments, should be involved, as indicated in [4]. Energy retrofitting options are studied as a socio-economical action towards NZEB

In the framework of the IEE, EU project EPISCOPE, a case study on refurbishment scenarios to achieve NZEB, [5], focuses on retrofitting of existing single-family house typology.

The EPISCOPE Project is a follow-up of the TABULA project (Typology Approach for Building Stock Energy Assessment) that was finalized to a classification scheme, grouping buildings according to their size, age and further parameters, and to define a set of exemplary buildings representing building types.

The European Commission has promoted several projects about the energy retrofit of existing buildings, directed to the NZEB target. Some of these projects give useful indications about the strategies to consider, like the following ones:

- ENTRANZE (policies to ENforce the TRAnsition to $\mathrm{NZEb}$ ), to support policy making by providing the required data, analyses and guidelines to achieve a fast and strong penetration of NZEB within the existing national building stocks,

- REPUBLIC ZEB (REfurbishment of the PUBLIC building stock towards nZEB), to indicate to the SouthEastern European countries the way to refurbish the existing public building stock towards Nearly Zero-Energy Buildings,

- RESHAPE (REtrofitting Social Housing and Active Preparation for Epbd), to help housing managers to define strategies for retrofitting and to get these issues across to tenants, apartment owners and housing cooperatives.

In building retrofit studies for NZEB, a starting point is the reduction of thermal energy-needs for the envelope. One of the main actions to reach this target is represented by the high thermal insulation of walls that can lead to significant energysaving results, depending on both the thermo-physical properties and the thickness of the materials adopted. However, some critical issues related to the risk of vapor condensation may arise depending on the position of the insulating materials used for the realization of insulation from the inside or in the air gap.

In a wider perspective, renovation actions on existing buildings (opaque envelope) should face not only the elements considered in the present research, but also other constraints and evaluations related for example to:

- use of sustainable materials;

- LCA;

- energy consumption reduction in summer conditions;

- $\quad$ seismic risk;

- fire protection;
- acoustic insulation

- economical evaluation of the retrofit actions.

Integrated design and multicriteria analyses can be appropriate to support designers and technicians' decisions. A study, on the building energy-efficiency improving, proposes a methodology to consider contemporarily a great number of variables [6]. Another, focusing on envelope elements [7], examines criteria for an efficient design, taking into account also sustainability protocols recommendations.

In the present analysis, the attention is centred on some basic aspects related to building energy performance in winter climatic conditions, represented by thermal characteristics of the opaque envelope, together with its moisture transfer properties.

Elements like acoustic, structural, fire resistance properties can be easily integrated in the methodological approach that will be here outlined and applied, considering thermal and hygrometric aspects of some building wall structures.

Therefore, the main target of the energy retrofit of buildings towards NZEB model is here discussed by means of a simple case-study.

Three external wall typologies, representing the building envelope of a little apartment, are tested referring to their thermal transmittance U. The U-value is compared with the limit values for NZEB and for refurbishment actions. Some retrofit hypotheses are examined to reach the NZEB target.

At the same time, the interstitial condensation risk is assessed, as strictly linked to wall layers composition.

The application of a thermal insulating layer that lead to a better energy performance may worsen the condensation risk.

A procedure for the integrated assessment is proposed and outlined. It can be applied to show when the NZEB target is possible to reach also in the building retrofit, and which attention must be made on other important aspects, like condensation.

\section{METHODOLOGY}

\subsection{Energy performance assessment}

As summarised in [8], the methodology for the energy performance assessment, indicated by the national Standard UNI TS 11300, Part 1-6 [9], is the national application of the European Standards elaborated under the M/480 Mandate [10]

Some parameters of the building energy balance are under the attention of the national laws that have imposed limit values with the aim to reduce energy consumption for new and refurbished buildings.

The main elements considered in the present analysis are the following ones:

- the thermal transmittance U;

- the $\mathrm{E}_{\mathrm{pH}, \mathrm{nd}}$, such as the ratio between the building energy need for continuous heating $\mathrm{Q}_{\mathrm{H}, \mathrm{nd}}$ and the net surface area $\mathrm{A}_{\mathrm{f}}$.

The term $\mathrm{Q}_{\mathrm{H}, \mathrm{nd}}$, in conditions of continuous heating, is calculated by [11]:

$$
\mathrm{Q}_{\mathrm{H}, \mathrm{nd}}=\left(\mathrm{Q}_{\mathrm{tr}}+\mathrm{Q}_{\mathrm{ve}}\right)-\eta_{\mathrm{H}, \mathrm{gn}}\left(\mathrm{Q}_{\mathrm{int}}+\mathrm{Q}_{\mathrm{sol}}\right)
$$

where:

- $\mathrm{Q}_{\mathrm{tr}}$ is the total heat transfer by transmission;

- $\mathrm{Q}_{\mathrm{ve}}$ is the total heat transfer by ventilation;

- Qint is the sum of internal heat gains;

- $\mathrm{Q}_{\text {sol }}$ is the sum of solar heat gains over the given period; 
- $\eta_{\mathrm{H}, \mathrm{gn}}$ is the dimensionless gain utilization factor.

In particular, $Q_{\text {tr }}$ depends also on temperature difference between indoor and outdoor environment $\left(\theta_{\mathrm{i}}-\theta \mathrm{e}\right)$, on the heating or cooling time period $\mathrm{t}$ and on $\mathrm{H}_{\mathrm{tr}}$, the overall heat transfer coefficient by transmission, determined by:

$\mathrm{H}_{\mathrm{tr}}=\mathrm{H}_{\mathrm{D}}+\mathrm{H}_{\mathrm{g}}+\mathrm{H}_{\mathrm{U}}+\mathrm{H}_{\mathrm{A}} \quad[\mathrm{W} / \mathrm{K}]$

where:

- $\mathrm{H}_{\mathrm{D}}$ is the direct heat transfer coefficient by transmission to the external environment;

- $\mathrm{H}_{\mathrm{g}}$ is the steady-state heat transfer coefficient by transmission to the ground;

- $\mathrm{H}_{\mathrm{U}}$ is the transmission heat transfer coefficient by transmission through unconditioned spaces;

- $\mathrm{H}_{\mathrm{A}}$ is the heat transfer coefficient by transmission to adjacent zone, maintained at different temperatures

In general, $\mathrm{H}_{\mathrm{x}}$, representing $\mathrm{H}_{\mathrm{D}}, \mathrm{H}_{\mathrm{g}}, \mathrm{H}_{\mathrm{U}}$, or $\mathrm{H}_{\mathrm{A}}$, consists of three terms [12]:

$\mathrm{H}_{\mathrm{x}}=\mathrm{b}_{\mathrm{tr}, \mathrm{x}}\left[\Sigma_{\mathrm{i}} \mathrm{A}_{\mathrm{i}} \mathrm{U}_{\mathrm{i}}+\Sigma_{\mathrm{k}} \mathrm{l}_{\mathrm{k}} \psi_{\mathrm{k}}+\Sigma_{\mathrm{j}} \chi_{\mathrm{j}}\right]$

where:

- $\mathrm{A}_{\mathrm{i}}$ is the area of the i-element of the building envelope $\left[\mathrm{m}^{2}\right]$;

- $\mathrm{U}_{\mathrm{i}}$ is the thermal transmittance of the i-element of the building envelope $\left[\mathrm{W} /\left(\mathrm{m}^{2} \mathrm{~K}\right)\right]$;

- $\mathrm{l}_{\mathrm{k}}$ is the length of the $\mathrm{k}$-linear thermal bridge $[\mathrm{m}]$;

- $\psi_{\mathrm{k}}$ is the linear thermal transmittance of the k-thermal bridge $[\mathrm{W} /(\mathrm{m} \mathrm{K})]$;

- $\chi_{\mathrm{j}}$ is the point thermal transmittance of the $\mathrm{j}$-point thermal bridge $[\mathrm{W} /(\mathrm{K})]$;

- $b_{t r, x}$ is the adjustment factor for the external temperature.

The limit values of some parameters used for the energy performance assessment are set at national level. For example in Italy, for building renovation, limits and parameters are depending on the extent of the adopted measures [13]:

A. Retrofit involving more than $50 \%$ of the building envelope (requirements for the entire building);

B. Retrofit involving more than $25 \%$ of the building envelope and possible intervention on the heating systems;

C. Energy refurbishment (actions on single building elements and/or heating systems not included in previous cases).

In setting-up the case-study building, the thermal features of some common Italian wall typologies will be considered to calculate not only the U-values but also the envelope energy performance index. The former will be compared with the maximum allowed U-values for the refurbishment and NZEB reported in Table 1 (Ref. Table 1, Appendix B, [13]), while the latter will be considered to give an indication about the corresponding reduced energy consumption.

\subsection{Hygrothermal performance assessment}

The EN ISO 13788 Standard [14] indicates the methodology to evaluate the moisture transfer through a wall as a function of the internal and external temperature and humidity, and of dimensional and thermo-physical properties of its layers. The procedure applies the Glaser method to assess interstitial condensation risk. The Standard suggests to consider verified a building wall, if the condensation can be completely dried throughout the year, and if it does not exceed the limit values of the materials involved.

The Italian national Decree [13] states that the walls must be completely free from the condensation risk.
Table 1. Maximum allowed U-values of external opaque building walls

\begin{tabular}{ccccc}
\hline $\begin{array}{c}\mathrm{U} \\
{\left[\mathrm{W} / \mathrm{m}^{2} \mathrm{~K}\right]}\end{array}$ & \multicolumn{2}{c}{ Walls } & \multicolumn{2}{c}{ Windows } \\
\hline $\begin{array}{c}\text { Climatic } \\
\text { zone }\end{array}$ & $\begin{array}{c}\text { refurbishment } \\
(2021)\end{array}$ & NZEB & $\begin{array}{c}\text { refurbishment } \\
(2021)\end{array}$ & NZEB \\
\hline A e B & 0.40 & 0.43 & 3.0 & 3.0 \\
\hline C & 0.36 & 0.34 & 2.0 & 2.2 \\
\hline D & 0.32 & 0.29 & 1.8 & 1.8 \\
\hline E & 0.28 & 0.26 & 1.4 & 1.4 \\
\hline F & 0.26 & 0.24 & 1.0 & 1.1 \\
\hline
\end{tabular}

\section{EVALUATION PROCEDURE PROPOSAL}

The calculation methodology, mainly aimed at achieving the energy saving objective, should be developed taking into account the constraints imposed at different levels: in this analysis, the results of the evaluations on a case-study are compared to meet both the minimum requirements about energy performance and the constraints about vapour condensation inside walls.

The procedure outlined is applied by considering some different climatic conditions to show if the results that meet the energy performance targets are also fulfilling the condensation risk assessment.

\subsection{Procedure}

The procedure here suggested can be outlined by the following steps (summarized in the flowchart shown in Fig.1).

1. Definition of the case study (a single building or an ensemble of similar buildings): wall's typologies (materials and layers order), envelope's geometry.

2. Boundary conditions: intended use, indoor climatic conditions, climatic zone (for Italy, according to [16]).

3. Evaluation methodologies:

3a) Energy performance calculations by means of the UNI TS 11300 part 1 Standard (representing the Italian application of the EN ISO 13790 Standard, [11])

3b) Hygrothermal performance of building walls by means of the EN ISO 13788 Standard that disciplines the

4. Existing configuration performance calculations:

4a) thermal transmittance $U$;

4b) vapour condensation risk assessment.

5. Target definition for each aspect considered in the global assessment. In the present procedure:

5a) for the energy evaluation, as first attempt the limits corresponding to NZEB (retrofit) are considered; as subsequent second attempt, the limits corresponding to refurbishment (due in 2021 for Italy) are assumed; 5b) absence of interstitial condensation risk

6. Retrofit: choice of the insulating material to be used for external, internal, air layer insulation and its thickness. The effect of any combination material/thickness should be verified from both the energy performance standpoint and the vapour condensation risk standpoint. A maximum number $i_{\max }$ of attempts to fulfil the NZEB requirements in terms of transmittance should be predefined, and sustainable materials should be investigated first. 
7. Refurbishment: choice of the insulating material to be used for external, internal, air layer insulation and its thickness. The effect of any combination material/thickness should be verified from both the energy performance standpoint and the vapour condensation risk standpoint. A maximum number $k_{\max }$ of attempts to fulfil the refurbishment requirements (due in 2021 for Italy) in terms of transmittance should be predefined, and sustainable materials should be investigated first. The combination material/thickness already considered in step 6 are likely to be the starting point for this step.

8. Output: according to the results obtained, the building under exam could turn out to be a NZEB (unlikely), to be retrofitted as a NZEB, to be refurbished to a good energy performance level, to require a complete rebuilding.

9. Cost optimal assessment (further development).

10. Choice of proper financial tool to apply the selected intervention (further development).

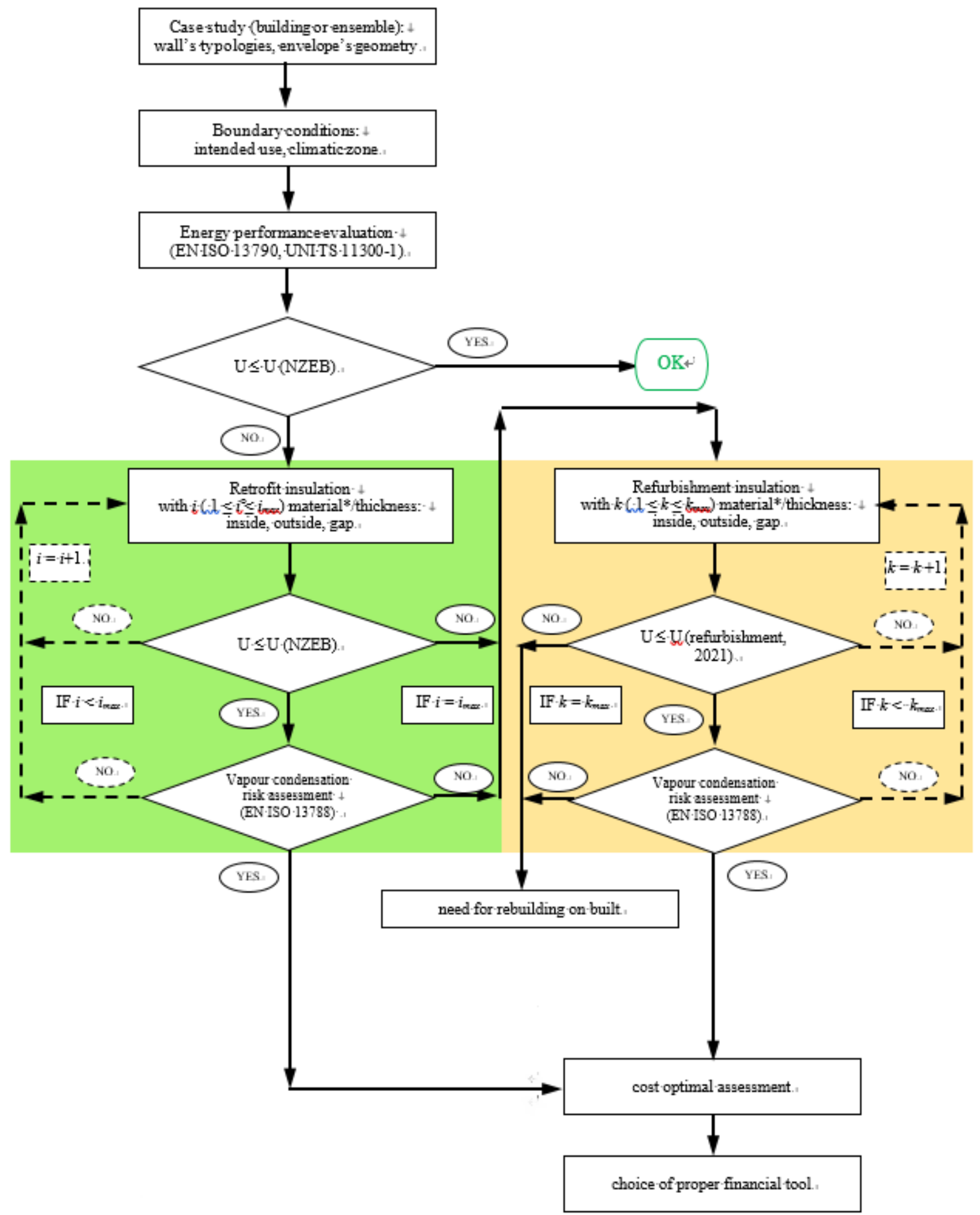

Figure 1. Procedure flow-chart 


\subsection{Case study}

To illustrate the calculation methodology, a case study is chosen according to the following premises. Buildings, which are typically critical from the energy standpoint, are represented by social housing buildings that are widespread in Italy. They do not have to respect constraints related to the architectural and historical value. Their energy retrofitting requires interventions on the building envelope, which therefore represents a starting point in order to reduce energy consumption.

The architectural and geometrical characteristics of the case study are chosen in order to represent a common little apartment in a tall building, with only one external wall (facing East, Fig.2), with windows. Its floor dimensions are $\mathrm{L}=10 \mathrm{~m}$, $\mathrm{D}=5 \mathrm{~m}$, with an internal height of $2.70 \mathrm{~m}$. The internal boundary walls face heated spaces and, thus, are not interested by heat transfer. To represent all the windows, only two large openings (height $2.5 \mathrm{~m}$, width $1.5 \mathrm{~m}$ ) are considered.

The thermophysical characteristics of three external wall typologies, which are representative of some social housing buildings [17], are indicated in Table 2. The windows U-value is assumed equal to $3.4 \mathrm{~W} / \mathrm{m}^{2} \mathrm{~K}$. Thermal bridges are here not considered to focus the attention only on the performance of the building wall and its layer composition rather than on its interaction with other structures.

The insulating materials considered for the energy retrofit of the existing walls are indicated in Table 3; only in one case (wall W1) there is an air layer that can be filled by means of loose insulating material. Its thickness is assumed equal to 10 $\mathrm{cm}$, which represents a common value.

The choice of the insulating materials is made on the basis of commonly used materials, easily available on the market. Moreover two typologies of materials for external/internal insulation and another two types, suitable for air layer insulation, have been considered, on the basis of the choice of more or less sustainable materials.

\subsection{Boundary conditions}

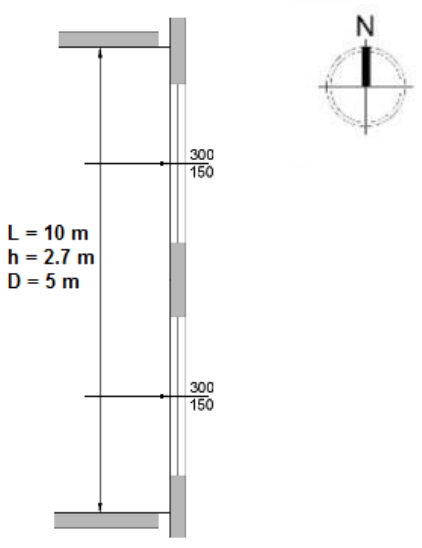

Figure 2. Detail of the external building wall (horizontal section): dimensions of opaque and transparent elements

The calculations have been made with reference to three climatic conditions that are typical of the northern, central and southern Italian territory, respectively.

Considering that Italy is divided into six climatic zones, corresponding to six thermal degree-days ranges, Milan, Genoa, Naples have been chosen to be representative of the three zones called E, D, C, respectively (see Table 4). Quite $92 \%$ of the Italian population lives in the municipalities of these zones [15].

Moreover these cities are characterised by a large diffusion of social housing buildings.

According to the intended use of the building (residential), the internal temperature is fixed equal to $20^{\circ} \mathrm{C}$.

Table 2. Building walls characteristics

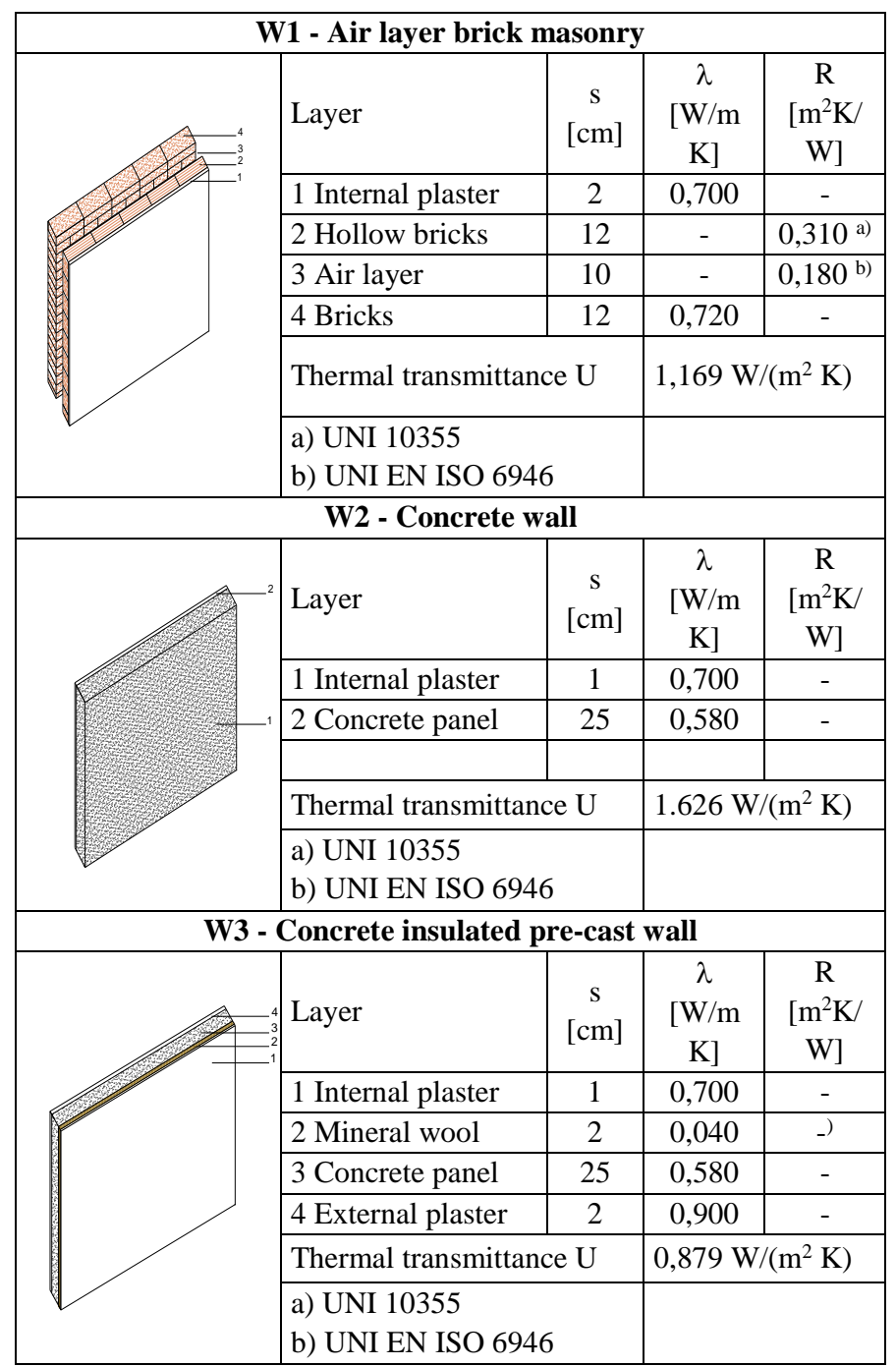

Table 3. Thermo-physical parameters of the chosen insulating materials

\begin{tabular}{cccc}
\hline Insulating materials & $\lambda[\mathbf{W} / \mathbf{m ~ K}]$ & $\boldsymbol{\rho}\left[\mathbf{k g} / \mathbf{m}^{3}\right]$ & $\begin{array}{c}\delta[\mathrm{kg} /(\mathbf{m ~ s} \\
\mathbf{P a})]\end{array}$ \\
\hline \multicolumn{2}{c}{ External/internal insulation } & & \\
\hline Wooden fibre board & 0.040 & 110 & $97 \mathbf{1 0}^{-\mathbf{1 2}}$ \\
\hline $\begin{array}{c}\text { Polystyrene } \\
\text { Air layer insulation }\end{array}$ & 0.033 & 35 & $1.3 \mathbf{1 0}^{-12}$ \\
\hline Cellulose & 0.038 & 35 & $1 \mathbf{1 0}^{-\mathbf{1 2}}$ \\
\hline Polyurethane foam & 0.030 & 30 & $3.8 \mathbf{1 0}^{-12}$ \\
\hline
\end{tabular}

Table 4. Climatic zones

\begin{tabular}{ccc}
\hline Location & Climatic zone & Degree days $\left[{ }^{\circ} \mathbf{C}\right.$ day] \\
\hline Milan & E & 2404 \\
Genoa & D & 1435 \\
Naples & C & 1034 \\
\hline
\end{tabular}




\section{RESULTS}

The results of the application of the proposed procedure to the case study are summarised in Tables 5a, b, c. In Tables 5a and $5 b$, the first column indicates the wall type (layer composition in Tab.2). In the second column, the reference town for the climatic conditions is specified. In column 3, the thermal transmittance of the existing wall is given. The group of columns 4 is different in the two Tables $5 \mathrm{a}$ and $5 \mathrm{~b}$, where the target U-values of the NZEB reference and of the building refurbishment, indicated by the Italian national Decree, are shown respectively. The groups 5 and 6 are referred to the two chosen insulating materials. The insulating material thickness, the corresponding $\mathrm{U}$-value and the percentage $\mathrm{EP}_{\mathrm{H} \text {,env }}$ reduction are reported. In each group, the last column shows the results of the condensation risk assessment, where "NO" indicates that the wall has not passed the check, and there is the possibility of condensation inside its layers, while "YES" implies the positive result, which means that the wall is free from condensation. In this column the results are indicated only for the internal insulation, as for the external insulation the vapour condensation assessment is positive for all the considered combinations insulating material/thickness, and all the three climatic conditions.

Table 5a. Energy performance and condensation risk results compared with the NZEB target

\begin{tabular}{|c|c|c|c|c|c|c|c|c|c|c|c|c|}
\hline \multirow{2}{*}{$\begin{array}{c}\mathbf{1} \\
\text { Wall }\end{array}$} & \multirow{2}{*}{$\begin{array}{c}\mathbf{2} \\
\text { Location }\end{array}$} & \multirow{2}{*}{$\begin{array}{c}3 \\
\mathrm{U}_{\text {exist }}\end{array}$} & \multicolumn{2}{|c|}{4 - U(NZEB) } & \multicolumn{4}{|c|}{5 - Wooden fibre insulation } & \multicolumn{4}{|c|}{ 6-Polystyrene insulation } \\
\hline & & & wall & window & Sinsul & $\mathrm{U}_{\text {insul }}$ & $\begin{array}{c}\mathrm{EP}_{\mathrm{H}, \mathrm{env}} \\
\text { reduction }\end{array}$ & $\begin{array}{l}\text { condensation } \\
\text { assessment** }\end{array}$ & Sinsul & $\mathrm{U}_{\text {insul }}$ & $\begin{array}{l}\mathrm{EP}_{\mathrm{H}, \mathrm{nd}} \\
\text { reduction }\end{array}$ & $\begin{array}{l}\text { condensation } \\
\text { assessment** }\end{array}$ \\
\hline \multirow{3}{*}{ W1 } & MI & \multirow{3}{*}{1.17} & 0.26 & 1.4 & 12 & 0.26 & $82 \%$ & $\mathrm{NO}$ & 10 & 0.26 & $82 \%$ & YES \\
\hline & GE & & 0.29 & 1.8 & 11 & 0.28 & $87 \%$ & YES & 9 & 0.28 & $87 \%$ & YES \\
\hline & NA & & 0.34 & 2.2 & 9 & 0.32 & $74 \%$ & YES & 7 & 0.33 & $73 \%$ & YES \\
\hline \multirow{3}{*}{$\mathrm{W} 2$} & MI & \multirow{3}{*}{1.63} & 0.26 & 1.4 & 13 & 0.26 & $85 \%$ & NO & 11 & 0.25 & $85 \%$ & YES \\
\hline & GE & & 0.29 & 1.8 & 12 & 0.28 & $90 \%$ & YES & 10 & 0.27 & $90 \%$ & YES \\
\hline & NA & & 0.34 & 2.2 & 10 & 0.32 & $78 \%$ & YES & 8 & 0.33 & $78 \%$ & YES \\
\hline \multirow{3}{*}{ W3 } & MI & \multirow{3}{*}{0.88} & 0.26 & 1.4 & 11 & 0.26 & $79 \%$ & NO & 9 & 0.26 & $79 \%$ & $\mathrm{NO}$ \\
\hline & GE & & 0.29 & 1.8 & 10 & 0.28 & $84 \%$ & YES & 8 & 0.28 & $84 \%$ & YES \\
\hline & NA & & 0.34 & 2.2 & 8 & 0.32 & $69 \%$ & $\mathrm{NO}$ & 6 & 0.34 & $67 \%$ & YES \\
\hline
\end{tabular}

Table 5b. Energy performance and condensation risk results compared with the refurbishment target (2021)

\begin{tabular}{|c|c|c|c|c|c|c|c|c|c|c|c|c|}
\hline \multirow{2}{*}{$\begin{array}{c}\mathbf{1} \\
\text { Wall }\end{array}$} & \multirow{2}{*}{$\begin{array}{c}\mathbf{2} \\
\text { Location }\end{array}$} & \multirow{2}{*}{$\begin{array}{c}3 \\
U_{\text {exist }}\end{array}$} & \multicolumn{2}{|c|}{$\begin{array}{c}\text { 4- U (refurbishment, } \\
\text { 2021) }\end{array}$} & \multicolumn{4}{|c|}{5 - Wooden fibre insulation } & \multicolumn{4}{|c|}{6 - Polystyrene insulation } \\
\hline & & & wall & window & Sinsul & $\mathrm{U}_{\text {insul }}$ & $\begin{array}{l}\mathrm{EP}_{\mathrm{H}, \mathrm{env}} \\
\text { reduction }\end{array}$ & $\begin{array}{l}\text { condensation } \\
\text { assessment** }\end{array}$ & Sinsul & $\mathrm{U}_{\text {insul }}$ & $\begin{array}{l}E P_{H, n d} \\
\text { reduction }\end{array}$ & $\begin{array}{l}\text { condensation } \\
\text { assessment*** }\end{array}$ \\
\hline \multirow{3}{*}{ W1 } & MI & \multirow{3}{*}{1.17} & 0.28 & 1.4 & 11 & 0.28 & $81 \%$ & NO & 9 & 0.28 & $81 \%$ & YES \\
\hline & GE & & 0.32 & 1.8 & 9 & 0.32 & $82 \%$ & YES & 8 & 0.30 & $84 \%$ & YES \\
\hline & NA & & 0.36 & $2.0^{*}$ & 8 & 0.35 & $77 \%$ & YES & 7 & 0.33 & $78 \%$ & YES \\
\hline \multirow{3}{*}{ W2 } & MI & \multirow{3}{*}{1.63} & 0.28 & 1.4 & 12 & 0.28 & $85 \%$ & NO & 10 & 0.27 & $85 \%$ & YES \\
\hline & GE & & 0.32 & 1.8 & 10 & 0.32 & $86 \%$ & YES & 9 & 0.30 & $88 \%$ & YES \\
\hline & NA & & 0.36 & $2.0^{*}$ & 9 & 0.35 & $81 \%$ & YES & 8 & 0.33 & $82 \%$ & YES \\
\hline \multirow{3}{*}{ W3 } & MI & \multirow{3}{*}{0.88} & 0.28 & 1.4 & 10 & 0.28 & $78 \%$ & $\mathrm{NO}$ & 8 & 0.28 & $77 \%$ & $\mathrm{NO}$ \\
\hline & GE & & 0.32 & 1.8 & 8 & 0.32 & $78 \%$ & YES & 7 & 0.31 & $80 \%$ & YES \\
\hline & NA & & 0.36 & $2.0^{*}$ & 7 & 0.35 & $73 \%$ & NO & 6 & 0.34 & $73 \%$ & YES \\
\hline
\end{tabular}

*anomalous value correctly taken by the national decree [13]

Table 5c. Energy performance and condensation risk results compared with the EPBD and refurbishment target (2021) for the air layer insulation

\begin{tabular}{|c|c|c|c|c|c|c|c|c|c|c|c|c|}
\hline \multirow{2}{*}{$\begin{array}{c}\mathbf{1} \\
\text { Wall }\end{array}$} & \multirow{2}{*}{$\begin{array}{c}\mathbf{2} \\
\text { Location }\end{array}$} & \multirow{2}{*}{$\begin{array}{c}\mathbf{3} \\
\mathrm{U}_{\text {exist }}\end{array}$} & \multicolumn{2}{|c|}{4 - U(NZEB) } & \multicolumn{2}{|c|}{$\begin{array}{c}\text { Cellulose } \\
\mathrm{U}=\mathbf{0 . 3 0} \mathrm{W} / \mathrm{m}^{2} \mathrm{~K}\end{array}$} & \multicolumn{2}{|c|}{$\begin{array}{l}\text { Polyurethane Foam } \\
\mathrm{U}=0.25 \mathrm{~W} / \mathrm{m}^{2} \mathrm{~K}\end{array}$} & \multicolumn{2}{|c|}{$\mathrm{U}$ (refurbishment, 2021) } & \multicolumn{2}{|c|}{$\begin{array}{c}\text { Cellulose } \\
\mathrm{U}=\mathbf{0 . 3 0} \mathrm{W} / \mathrm{m}^{2} \mathrm{~K}\end{array}$} \\
\hline & & & wall & window & $\begin{array}{l}\mathrm{EP} H, \text { nd } \\
\text { reduction }\end{array}$ & $\begin{array}{c}\text { condensation } \\
\text { assessment }\end{array}$ & $\begin{array}{l}\mathrm{EP}_{\mathrm{H}, \mathrm{nd}} \\
\text { reduction }\end{array}$ & $\begin{array}{c}\text { condensation } \\
\text { assessment }\end{array}$ & wall & window & $\begin{array}{c}\mathrm{EP}_{\mathrm{H}, \mathrm{nd}} \\
\text { reduction }\end{array}$ & $\begin{array}{l}\text { condensation } \\
\text { assessment* }\end{array}$ \\
\hline \multirow{3}{*}{ W1 } & MI & \multirow{3}{*}{1.17} & 0.26 & 1.4 & - & & $82 \%$ & YES & 0.28 & 1. & & \\
\hline & GE & & 0.29 & 1.8 & - & & $88 \%$ & YES & & 1. & $84 \%$ & YES \\
\hline & NA & & 0.34 & 2.2 & $75 \%$ & YES & $78 \%$ & YES & 0.36 & $2.0^{*}$ & not needed & \\
\hline
\end{tabular}

Note: the air layer thickness is equal to $\mathrm{s}=10 \mathrm{~cm}$

In Table 5c the results of the air layer insulation are summarised for wall $\mathrm{W} 1$, the only one with an air layer that can be filled with an insulating material.

The U(NZEB) target, imposed by the Italian national Decree [13], is reached with cellulose filling only for Naples, as its corresponding limit is higher. The U-value obtained with the polyurethane foam is lower, and therefore it satisfies the limits for all the three locations. The condensation risk assessment leads to a positive result for all the conditions: the walls are free from condensation. The attempt to satisfy at least the requirement for the building refurbishment allows considering also this measure for the climatic conditions of Genoa, while for Milan it is not feasible. In this last case, it will be possible to plan a double intervention, in the air layer 
and on the wall surface.

The calculations were performed by neglecting the thermal bridge effects, to focus the attention on the relation between the wall $U$-values and the energy performance index in the heating season for building envelope, $\mathrm{Ep}_{\mathrm{H}, \mathrm{env}}$. Moreover the net heated volume is considered not reduced by the presence of the insulating layer, when applied on the internal side.

The insulating materials chosen both for external/internal and for air layer insulation are representative of different degrees of sustainability.

In order to compare the thicknesses of the insulating material that respect the U(NZEB) limit, the results of Table $5 \mathrm{a}$ and $5 \mathrm{~b}$ are represented in Fig.3,4,5 for W1, W2, W3 walls typologies respectively.

The data refer to the climatic conditions of Milan (MI), Genoa (GE) and Naples (NA), and to internal and external insulation.

The U(NZEB) values, indicated with the grey large bars in the background, refer to the left axis scale, while the heights of brown and blue bars, representing the insulating layer thicknesses, can be read on the right axis. The thicknesses represent the minimum values that allow reaching the U(NZEB) target. They can be quite high for the application on the internal side of the wall, for the significant internal volume reduction, while they seem acceptable for external insulation.

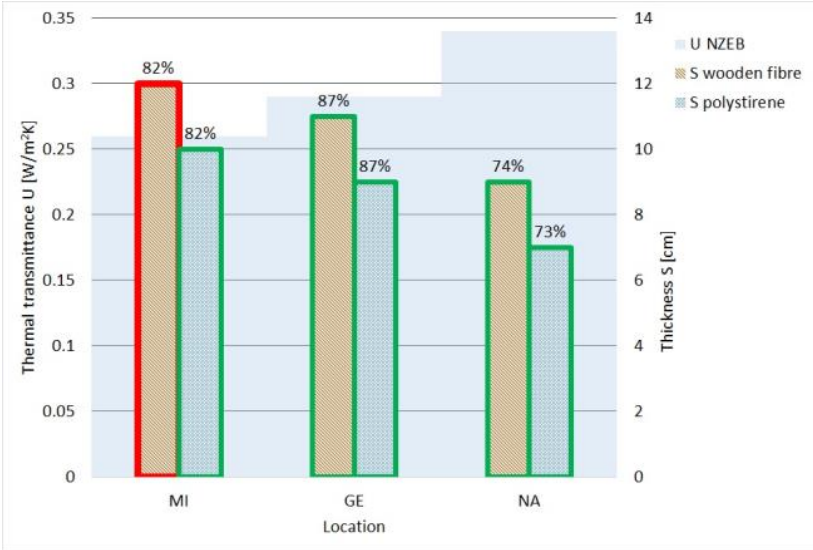

Figure 3. W1 building wall: thicknesses of wooden fibre and polystyrene panels to respect U(NZEB) target in different climatic conditions

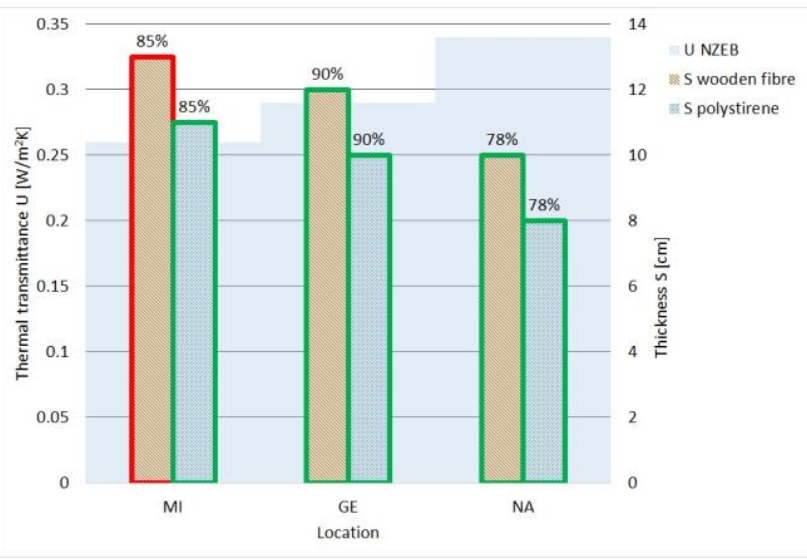

Figure 4. W2 building wall: thicknesses of wooden fibre and polystyrene panels to respect U(NZEB) target in different climatic conditions

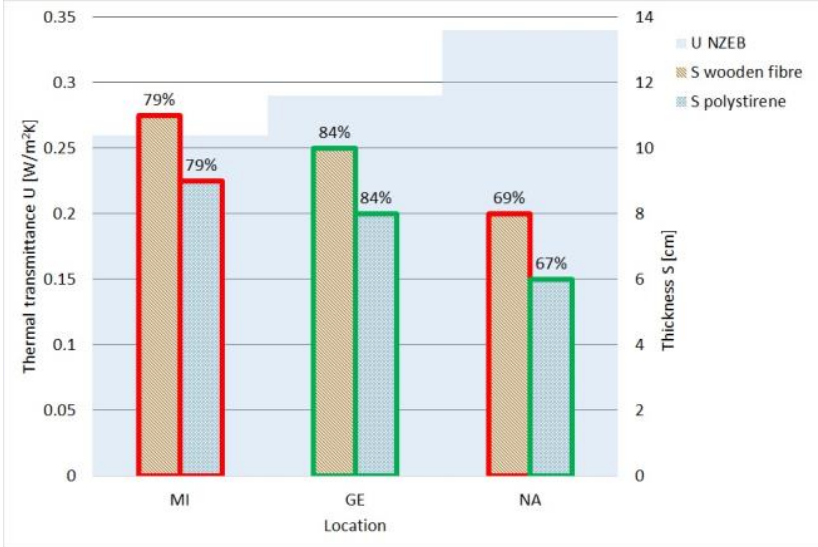

Figure 5. W3 building wall: thicknesses of wooden fibre and polystyrene panels to respect U(NZEB) target in different climatic conditions

The percentage reduction in energy need, obtained with the insulating material, is shown on the top of each bar, demonstrating very good results in term of energy saving.

The green and red edges indicate respectively the positive and negative assessment of the condensation risk, with the insulation layer positioned on the internal wall face. For the wooden fibre insulation, the $\mathrm{W} 1$ and $\mathrm{W} 2$ walls are critical only for the climatic conditions of Milan, while they are always positive in the other two locations.

The W3 wall is critical in two sites (Milan and Naples), with wooden fibre insulation, and it remains critical in Milan also with the polystyrene insulation. In this case, the procedure application shows that this wall structure cannot satisfy both the assessments, and therefore it is impossible to plan this kind of intervention to reach the U(NZEB) target, by means of internal insulation.

\section{CONCLUSIONS}

In this work a procedure for the energy renovation design of building walls has been proposed. It takes into account two important aspects that regard both the thermal and the hygrometric properties of building materials but it can be easily extended to other elements (i.e acoustic properties and constraints, fire requirements, etc.).

The methodological approach is applied in accordance to the Italian national transposition of the EPBD, and in respect of the national requirements for building renovation.

The ambitious goal to reach the NZEB target is investigated by insulating three wall structures commonly used in existing social housing, taking into account typical climatic conditions of northern, central, southern Italy.

The results lead to a deeper awareness about the need for simultaneous assessment of thermal and moisture problems, for a careful selection of materials and their correct positioning according to the climatic conditions.

The use of sustainable materials doesn't allow to fulfil always the requirements for both the aspects. In details, the NZEB target can be reached with high values of the insulating layer thickness, for sustainable material, in colder climate. However, the condensation risk could not be assessed for internal insulation.

On the other hand, the choice of less sustainable materials can help satisfying both the limits of the considered aspects, 
with slightly thinner insulation.

The procedure shown in the present paper, with reference to the heating period, will be applied also to the cooling period in a future research, where the main aspects characterizing the summer regime will be investigated.

\section{REFERENCES}

[1] Directive 2010/31/EU of the European Parliament and of Council of 19 May 2010 on the energy performance of building (recast), Official Journal of the European Union, 18.02.2010

[2] 2012/C 115/01, Guidelines accompanying Commission Delegated Regulation (EU) No 244/2012 of 16 January 2012 supplementing Directive 2010/31/EU of the European Parliament and of the Council on the energy performance of buildings by establishing a comparative methodology framework for calculating cost-optimal levels of minimum energy performance requirements for buildings and building elements, Official Journal of the European Union, ISSN 1977-091X, Vol. 55, Apr. 2012.

[3] Magrini A., Magnani L., Pernetti R. (2012). The effort to bring existing buildings towards the A class: A discussion on the application of calculation methodologies, Applied Energy, Vol. 97, pp. 438-450. DOI: 10.1016/j.apenergy.2012.01.012

[4] Ferrante A. (2014). Energy retrofit to nearly zero and socio-oriented urban environments in the Mediterranean climate, Sustainable Cities and Society, Vol. 13, pp. 237-253. DOI: 10.1016/j.scs.2014.02.001

[5] Serghides D.K., Dimitriou S., Katafygiotou M.C., Michaelidou M. (2015). Energy efficient refurbishment towards nearly zero energy houses, for the mediterranean region, Energy Procedia, Vol. 83, pp. 533-543. DOI: $\underline{10.1016 / j . e g y p r o .2015 .12 .173}$

[6] Kaklauskas A., Kazimieras Zavadskas E., Raslanas S. (2005). Multivariant design and multiple criteria analysis of building refurbishments, Energy and Buildings, Vol. 37, pp. 361-372. DOI: 10.1016/j.enbuild.2004.07.005

[7] Baglivo C., Congedo P.M. (2016). High performance precast external walls for cold climate by a multicriteria methodology, Energy, Vol. 115, Part 1, pp. 561576. DOI: $10.1016 /$ j.energy.2016.09.018

[8] Magrini A., et al. Building Refurbishment for Energy Performance - A Global Approach, Ed. Springer International, ISBN 978-3-319-03073-9

[9] UNI/TS 11300 Energy performance of buildings, Part 1: Evaluation of energy need for space heating and cooling, Part 2: Evaluation of primary energy need and of system efficiencies for space heating, domestic hot water production, ventilation and lighting for nonresidential buildings, Part 3: Evaluation of primary energy and system efficiencies for space cooling, Part 4: Renewable energy and other generation systems for space heating and domestic hot water production, Part 5 Evaluation of energy performance for the classification of building, Part 6 Evaluation of energy need for lift, escalators and moving walkways.

[10] M/480 Mandate to CEN, CENELEC and ETSI for the elaboration and adoption of standards for a methodology calculating the integrated energy performance of buildings and promoting the energy efficiency of buildings, in accordance with the terms set in the recast of the Directive on the energy performance of buildings

(2010/31/EU),

http://ec.europa.eu/growth/tools-

databases/mandates/index.cfm?fuseaction=search.det ail\&id=465

[11] CEN: Energy performance of buildings. Calculation of energy use for space heating and cooling, EN ISO 13790 European Committee for Standardization

[12] CEN: Thermal performance of buildings. Transmission and ventilation heat transfer coefficients - Calculation method, EN ISO 13789, European Committee for Standardization

[13] Interministerial Decree, June 26, 2015 - Application of the energy performance calculation methodologies and definition of dispositions and minimum requirements for buildings

[14] CEN: Hygrothermal performance of building components and building elements - Internal surface temperature to avoid critical surface humidity and interstitial condensation - Calculation methods, EN ISO 13788:2013, European Committee for Standardization

[15] Italian Ministry of Economic Development and of the Environment, Strategy for the energy refurbishment of the national building stock (STREPIN), www.mise.gov.it

[16] Italian National Decree D.P.R. 412/1993, Regolamento recante norme per la progettazione, l'installazione, l'esercizio e la manutenzione degli impianti termici degli edifici ai fini del contenimento dei consumi di energia, in attuazione dell'art.4, comma 4, della legge 09.01.1991, n.10 (Regulations for the design, installation, operation and maintenance of heating systems in buildings in order to limit energy consumption, implementing article 4, paragraph 4 , of Law 09.01.1991, n. 10)

[17] Franco G. (2003). L'involucro edilizio. Guida alla progettazione e alla manutenzione delle chiusure verticali portate e portanti, (Building envelope. Guide to the design and maintenance of the external walls of buildings), EPC Libri, Roma, p. 240 pagg, ISBN 888184-303-X

\section{NOMENCLATURE}

$\mathrm{A}_{\mathrm{f}} \quad$ internal floor area of the conditioned space, $\mathrm{m}^{2}$

$\mathrm{A}_{\mathrm{i}} \quad$ area of the i-element of the building envelope, $\mathrm{m}^{2}$

$b_{t r}$ adjustment factor for the external temperature

$\mathrm{EP}_{\mathrm{H}}$ energy performance index in the heating season, $\mathrm{kWh} . \mathrm{m}^{-2}$. year $^{-1}$

$\mathrm{EP}_{\mathrm{H} \text {,env }}$ energy performance index in the heating season for building envelope, $\mathrm{kWh} . \mathrm{m}^{-2}$. year ${ }^{-1}$

$\mathrm{H}_{\mathrm{D}} \quad$ direct heat transfer coefficient by transmission to the external environment, W. $\mathrm{K}^{-1}$

$\mathrm{H}_{\mathrm{g}}$ steady-state heat transfer coefficient by transmission to the ground, W. $\mathrm{K}^{-1}$

$\mathrm{H}_{U}$ transmission heat transfer coefficient by transmission through unconditioned spaces, W.K.1

$\mathrm{H}_{\mathrm{A}} \quad$ heat transfer coefficient by transmission to adjacent zone, maintained at different temperatures, W. $\mathrm{K}^{-1}$

$\mathrm{H}_{\mathrm{x}} \quad$ general expression of $\mathrm{H}_{\mathrm{D}}, \mathrm{H}_{\mathrm{g}}, \mathrm{H}_{\mathrm{U}}$, or $\mathrm{H}_{\mathrm{A}}$ 
$l_{\mathrm{k}} \quad$ length of the $\mathrm{k}$-linear thermal bridge, $\mathrm{m}$

$Q_{\mathrm{H}, \mathrm{gn}}$

$Q_{\mathrm{H}, \mathrm{nd}}$

$Q_{\text {int }}$

$Q_{\text {sol }}$

$Q_{\text {tr }}$

$Q_{\mathrm{ve}}$

$R$

$\mathrm{S}$

U total heat gains for the heating mode, MJ

building energy need for continuous heating, MJ

sum of internal heat gains, MJ

sum of solar heat gains over the given period, MJ

total heat transfer by transmission, MJ

total heat transfer by ventilation, $\mathrm{MJ}$

thermal resistance, $\mathrm{m}^{2} . \mathrm{K} . \mathrm{W}^{-1}$

thickness, $\mathrm{cm}$

thermal transmittance, W. $\mathrm{m}^{-2} \cdot \mathrm{K}^{-1}$

\section{Greek symbols}

$\delta \quad$ vapour permeability, $\mathrm{kg} \cdot \mathrm{m}^{-1} \cdot \mathrm{s}^{-1} \cdot \mathrm{Pa}^{-1}$

$H, g n \quad$ gain utilization factor

$\theta_{i} \quad$ internal temperature, ${ }^{\circ} \mathrm{C}$

$\theta_{e} \quad$ external temperature, ${ }^{\circ} \mathrm{C}$

$\lambda$ thermal conductivity, $\mathrm{W} \cdot \mathrm{m}^{-1} \cdot \mathrm{K}^{-1}$

$\rho \quad$ density, $\mathrm{kg} . \mathrm{m}^{-3}$

$\chi_{j} \quad$ point thermal transmittance of the $\mathrm{j}$-point thermal bridge, W. $\mathrm{K}^{-1}$

$\psi_{k} \quad$ linear thermal transmittance of the $\mathrm{k}$-thermal bridge, $\mathrm{W} \cdot \mathrm{m}^{-1} \cdot \mathrm{K}^{-1}$ 